\title{
Therapeutic monitoring of amiodarone: pharmacokinetics and evaluation of the relationship between effect and dose/concentration
}

\author{
Erika Hrudikova Vyskocilova ${ }^{\mathrm{a}, \mathrm{b}}$, Milan Grundmann ${ }^{\mathrm{a}}$, Jana Duricova ${ }^{\mathrm{a}, \mathrm{b}}$, Ivana Kacirova ${ }^{\mathrm{a}, \mathrm{b}}$
}

\begin{abstract}
Amiodarone is the most effective agent in the therapy of arrhythmias. However, the clinical effect of acute and chronic treatment is unclear and there are differences irrespective of comparable plasma/myocardial amiodarone and its metabolite desethylamiodarone concentations as well. Its unusual pharmacokinetics results in interindividual variation in plasma levels. The association between amiodarone and desethylamiodarone plasma levels and clinical efficacy is difficult to evaluate. This review was carried out to assess whether there is any objective correlation between amiodarone and desethylamiodarone plasma levels and the clinical effect. We summarized the results of relevant studies and clarified the relationship between plasma levels and effect vis á vis the pharmacokinetics and pharmacogenetics of this drug. Certain correlation was seen with oral amiodarone therapy, in others, plasma amiodarone levels were unrelated to therapeutic response and showed no correlation with changes in electrocardiogram or electrophysiological parametres. Several studies show that plasma concentration ranging between 0.5 and $2.5 \mathrm{mg} / \mathrm{L}$ appears to be the most effective, others demonstrate no difference between responders and non-responders. One way of interpreting plasma levels is to establish an individual patient's effective concentration. Therapeutic drug monitoring can contribute to determining optimal concentration.
\end{abstract}

Key words: amiodarone, pharmacokinetics, effects, therapeutic drug monitoring

Received: July 27, 2016; Accepted with revision: March 22, 2017; Available online: March 31, 2017 https://doi.org/10.5507/bp.2017.016

${ }^{a}$ Department of Clinical Pharmacology, Faculty of Medicine, University of Ostrava, Czech Republic 'Institute of Clinical Pharmacology, Department of Laboratory Diagnostics, University Hospital Ostrava, Czech Republic Corresponding author: Milan Grundmann, e-mail:milan.grundmann@seznam.cz

\section{INTRODUCTION}

Amiodarone is the most effective antiarrhythmic medications available today for the treatment of both atrial and ventricular arrhythmias. Its efficacy is likely related to diverse effects on a number of cardiac receptors and ionic currents ${ }^{1}$.

\section{Pharmacokinetics}

Amiodarone has a large individual variation in systemic bioavailability after oral administration ${ }^{2}$ because gastrointestinal absorption appears to be slow and incomplete ${ }^{3}$. The relatively poor bioavailability is probably mediated by intestinal wall metabolism via CYP3A4 in addition to gastrointestinal excretion mediated by P-glycoprotein. DEA inhibits the activities of both CYP3A4 and P-glycoprotein, thus it is suggested that the bioavailability of amiodarone is gradually increased over time in patients receiving longterm amiodarone therapy ${ }^{4}$. The time from oral intake to the peak serum concentration $\left(\mathrm{C}_{\max }\right)$ was estimated to be about $7.3 \mathrm{~h}\left(\right.$ ref. $\left.^{3}\right) . \mathrm{AUC}_{0-\infty}$ after the first oral dose was more than three times lower than the $\mathrm{AUC}_{0-24 \mathrm{~h}}$ after the $9^{\text {th }}, 37^{\text {th }}$, and $11^{\text {th }}$ dose in three patients (AUC normalized for the dose) (ref. $\left.{ }^{2}\right)$.

In the case of intravenous administration the $\mathrm{C}_{\max }$ of amiodarone after a 15 -min intravenous infusion of $5 \mathrm{mg} / \mathrm{kg}$ ranged between 8.604 and $19.441 \mathrm{mg} / \mathrm{L}$, even with $100 \%$ bioavailability 5 .
Amiodarone is highly bound to human plasma proteins. Its free fraction is independent of the total drug concentration and albumin level, indicating that the binding is not concentration dependent over the normal therapeutic range ${ }^{6}$. There is some evidence that DEA is less lipid soluble than the parent compound and is somewhat less protein-bound ${ }^{7}$. Amiodarone is high lipid-soluble. This could lead to a large volume of distribution (Vd) $\left(\right.$ ref. $\left.^{8}\right)$. Duration of administration is a crucial factor in determining the volume of deep compartments. With studies of shorter administration less drug has time to enter the peripheral compartments, therefore the deep compartments appear smaller. It is quite possible that a true steady state in terms of volume of distribution and elimination is never reached but rather amiodarone continues to accumulate with long-term therapy ${ }^{9}$.

The highest concentrations of amiodarone were found in fat, liver, bone marrow, and lung tissue. It was shown that DEA was present in these tissues at several-fold higher concentrations than the parent compound, except for fat tissue ${ }^{10}$. This tendency of DEA to accumulate in tissues more than amiodarone is in agreement with the higher red blood cell/plasma ratio of this compound ${ }^{11}$. With regard to myocardium, it was shown that the range of amiodarone concentration was wide after rapid intravenous administration. This variability may explain the time of myocardial sampling after amiodarone injection, as well as differences in the patients ' body weights, in 
the variable regional coronary blood flow from patient to patient at the time of sampling, in the extent of myocardial fibrosis, and in the variations in myocardial concentration dependent on the specific site and depth of biopsy ${ }^{12}$. There was also demonstrated placental transfer of amiodarone and DEA in humans ${ }^{13}$. It is surprising that even at steady state, plasma amiodarone concentrations can be expected to fall by $25 \%$ within a few days of the cessation of therapy and $50 \%$ in 36 days. Thus a 2- to 3-day interruption of dosing could produce a clinically useful decrease in concentration, potentially providing relief to patients with acute onset of bradycardia, tremor, ataxia, or gastrointestinal distress ${ }^{9}$. Although miniscule amounts of amiodarone can be detected in serum for up to 9 months, these minimal concentrations are unlikely to confer antiarrhythmic protection ${ }^{10}$.

After administration of a single dose of amiodarone, a wide interpatient variable half-life $\left(t_{1 / 2}\right)$ is found ${ }^{2}$. After intravenous administration the drug concentration declined during the second phase with a mean half-life of $4.3 \mathrm{~h}$ $\left(\right.$ ref. $\left.{ }^{14}\right)$. The initial rapid elimination phase was observed within 3-5 min, and the serum concentration declined to less than $2.0 \mathrm{mg} / \mathrm{L}$ within $30-45 \mathrm{~min}$ after completion of the infusion. This initial decrease in serum concentration might be due to uptake into peripheral tissues high in fat. In contrast, the elevation of DEA concentrations lagged behind the change in amiodarone concentrations, which were also below clinically effective levels. This discrepancy presumably reflects slow biotransformation of the parent $\mathrm{drug}^{5}$. The slow elimination may be understood conceptually by means of a multicompartment model. The long life of the terminal elimination phase of the plasma curve reflects the slow release of amiodarone from the reservoir, or deep compartment, into the plasma ${ }^{15}$.

Cytochrome P450 3A4 (CYP) is the major isoform involved in amiodarone metabolism. Amiodarone undergoes deethylation to the major metabolite DEA and it is further metabolized by CYP3A4 to subsequent metabolites ${ }^{16}$. DEA (probably together with amiodarone) is degraded to other compounds by hydroxylation ${ }^{17}$. Furthermore, CYP 2C8 and CYP1A1 may also significantly contribute to amiodarone metabolism ${ }^{18}$.

CYP3A4 which constitutes $30 \%$ of the total CYP content in human liver is expected to be the major iso- form involved in amiodarone metabolism. The activity of CYP1A1 might vary depending on smoking status as smoking has been shown to induce CYP1A1 metabolic activity. In this condition, the DEA formation by human CYP1A1 might however be a consideration ${ }^{19}$. CYP2C8 activity might be influenced by genetic polymorphism. Soyama et al. showed that the variant CYP2C8 P404A but not CYP2C8*3 has a lower intrinsic clearance for amiodarone $\mathrm{N}$-deethylation compared with $\mathrm{CYP} 2 \mathrm{C} 8 * 1$. These authors suggested that polymorphic alleles of CYP2C8 may lead to variations in the clinical response to amiodarone ${ }^{20}$. A higher frequency of variant CYP2C8 alleles is expected in Caucasian Americans with a Southern European ancestry than in individuals with Northern European ancestry $^{21}$. The contribution of other metabolite enzymes, CYP1A2, CYP2C19, or CYP2D6, to amiodarone metabolism seems to be minor, these isoforms might alternatively contribute to metabolism in clinical situations in which CYP3A4 or CYP2C8 is inhibited by coadministered drugs ${ }^{18}$. Less than $1 \%$ of the dose is excreted unchanged in the urine ${ }^{22}$ therefore minimal fluctuations of serum levels between dialysis are observed ${ }^{23}$. The ratio of DEA to amiodarone remained relatively constant over different dosage or drug concentration ranges, but increased with duration of treatment (reaching approximately $80 \%$ than of amiodarone after several months), suggesting a timedependent metabolic function ${ }^{11}$. Individual variation of the clearance decreases in subjects receiving long-term amiodarone therapy ${ }^{4}$. Age-related changes in amiodarone and DEA disposition have been shown, but their clinical relevance appears negligible ${ }^{24}$. The pharmacokinetics profile of amiodarone is summarized in Table 1.

\section{MECHANISM OF ACTION}

The cellular actions of amiodarone differ somewhat in acute compared to chronic administration ${ }^{25}$.

\section{Acute therapy}

Acute amiodarone therapy results in a use-dependent inhibition of inward sodium (Vaughan-Williams class I effect) and inward calcium currents (Vaughan-Williams class IV effect) $\left(\right.$ ref. $\left.^{26}\right)$, as well as a non-competitive al-

Table 1. Amiodarone pharmacokinetic profile $e^{(9,10,15,24)}$.

\begin{tabular}{ll}
\hline pharmacokinetic parameter & \\
\hline binding to plasma proteins & $<99 \%$ \\
Vd & $50-100 \mathrm{~L} / \mathrm{kg}$ \\
Metabolism & CYP3A4, 1A1, 2B6 \\
enzyme inhibition & CYP3A4, 1A1, 1A2, 2B6, 2C9, 2D6 \\
clearance (amiodarone) after single dose i.v. administraton & $90-158 \mathrm{~mL} / \mathrm{h} / \mathrm{kg}$ \\
clearance (desethylamiodarone) after single dose i.v. administraton & $197-290 \mathrm{~mL} / \mathrm{h} / \mathrm{kg}$ \\
Excretion & bile, renal elimination is minimal \\
$\mathrm{t}_{1 / 2}$ (amiodarone) after single dose & $11-20 \mathrm{~h}$ \\
$\mathrm{t}_{1 / 2}$ (amiodarone) after long-term therapy & mean 50 days \\
$\mathrm{t}_{1 / 2}$ (desethylamiodarone) after long-term therapy & mean 60 days \\
\hline
\end{tabular}

$\mathrm{Vd}$ - volume of distribution, $\mathrm{t}_{1 / 2}$ - elimination half-life 
Table 2. Intravenous administration of amiodarone (DEA levels were not measured.

\begin{tabular}{|c|c|c|c|c|c|}
\hline $\mathrm{n}$ & Dosage & $\begin{array}{l}\text { Amiodarone } \\
(\mathrm{mg} / \mathrm{L})\end{array}$ & $\begin{array}{l}\text { Type } \\
\text { of arrhythmia }\end{array}$ & Effect & Ref. \\
\hline 5 & $5-10 \mathrm{mg} / \mathrm{kg}$ & & Sustained VT & Terminated within $20 \mathrm{~min}$ in all patients & 10 \\
\hline 9 & $5 \mathrm{mg} / \mathrm{kg}$ & $3.1 \pm 1.8$ & $\begin{array}{l}\text { AV nodal reentrant tachycardia } \\
\text { (AVRNT) }\end{array}$ & $\begin{array}{l}\text { AVRNT terminated in } 7 \text { patients, reinducible } \\
\text { tachycardia in } 3 \text { patients }\end{array}$ & 49 \\
\hline 9 & $\begin{array}{l}10-20 \mathrm{mg} / \mathrm{kg} / \text { day } \\
\text { for } 4-7 \text { days }\end{array}$ & $1.7 \pm 1.0$ & $\begin{array}{l}\text { Refractory sustained ventricular } \\
\text { tachycardia }\end{array}$ & Terminated in 5 patients & 50 \\
\hline 8 & $125 \mathrm{mg} /$ day & & Incessant VT & Terminated in $0.94 \mathrm{~h}$ & 42 \\
\hline 14 & $500 \mathrm{mg} /$ day & & & Terminated in $1.92 \mathrm{~h}$ & \\
\hline 15 & $1000 \mathrm{mg} /$ day & & & Terminated in $0.85 \mathrm{~h}$ & \\
\hline 13 & $125 \mathrm{mg} /$ day & & Incessant VT & Terminated in $4.58 \mathrm{~h}$ & 51 \\
\hline 12 & $1000 \mathrm{mg} /$ day & & & Terminated in $4.23 \mathrm{~h}$ & \\
\hline 78 & $525 \mathrm{mg} /$ day & & VT & Successful response during $6-24 \mathrm{~h}$ in $41 \%$ & 52 \\
\hline 80 & $1050 \mathrm{mg} /$ day & & & Successful response during $6-24 \mathrm{~h}$ in $45 \%$ & \\
\hline 79 & $2100 \mathrm{mg} /$ day & & & Successful response during $6-24 \mathrm{~h}$ in $53 \%$ & \\
\hline
\end{tabular}

$\mathrm{n}$ - number of patient

Table 3. Oral administration of amiodarone.

\begin{tabular}{|c|c|c|c|c|c|c|}
\hline $\mathrm{n}$ & Dosage & Amiodarone $(\mathrm{mg} / \mathrm{L})$ & $\begin{array}{l}\text { DEA } \\
(\mathrm{mg} / \mathrm{l})\end{array}$ & $\begin{array}{l}\text { Type } \\
\text { of arrhythmia }\end{array}$ & Effect & Ref. \\
\hline 18 & single dose $30 \mathrm{mg} / \mathrm{kg}$ & $\begin{array}{l}5.2 ; 8.6 \\
\text { (in } 2 \text { patients) }\end{array}$ & & Permanent AF & $\begin{array}{l}\text { Sinus rhythm restored in } 5 \\
\text { patients within } 5 \pm 1.5 \mathrm{~h}\end{array}$ & 54 \\
\hline 17 & single dose $30 \mathrm{mg} / \mathrm{kg}$ & $\begin{array}{l}71 \% \text { reached median } \\
\text { concentration } 2.4 \\
\text { (range } 0.96-4.7 \text { ) }\end{array}$ & $<0.2$ & Chronic atrial tachycardia & $\begin{array}{l}\text { No patients converted } \\
\text { pharmacodynamically to } \\
\text { sinus rhythm within } 24 \mathrm{~h}\end{array}$ & 55 \\
\hline 129 & $600 \mathrm{mg} /$ day & $\begin{array}{l}\cdot 2.0 \pm 0.8 \\
\cdot 1.4 \pm 0.7\end{array}$ & $\begin{array}{l}\cdot 1.4 \pm 0.7 \\
\cdot 1.0 \pm 0.5\end{array}$ & $\begin{array}{l}\text { Refractory atrial } \\
\text { fibrillation/ flutter }\end{array}$ & $\begin{array}{l}\text { - } 23 \text { patients converted to } \\
\text { sinus rhythm during a } \\
\text { 4-week period } \\
\text { - } 106 \text { patients not converted } \\
\text { to sinus rhythm during a } \\
\text { 4-week period }\end{array}$ & 56 \\
\hline 23 & $\begin{array}{l}\text { - initial doses } \\
600-2000 \mathrm{mg} / \text { day, } \\
\text { average maintenance } \\
\text { dose } 713 \mathrm{mg} / \text { day } \\
\text { - initial doses } \\
\text { 600-2000 mg/day, } \\
\text { average maintenance } \\
\text { dose } 375 \mathrm{mg} / \text { day }\end{array}$ & & & $\begin{array}{l}\text { Sustained, recurrent, } \\
\text { symptomatic VT }\end{array}$ & $\begin{array}{l}\text { - No recurrences during a } \\
\text { follow-up of } 21.5 \text { months in } \\
15 \text { patients } \\
\text { - Isolated recurrences during } \\
\text { a follow-up of } 32.2 \text { months } \\
\text { in } 5 \text { patients }\end{array}$ & 57 \\
\hline $8 / 10$ & $1600-4400 \mathrm{mg} /$ day & $2.08-2.80$ & $0.60-0.75$ & $\begin{array}{l}\text { Refractory, sustained, } \\
\text { hemodynamically com- } \\
\text { promising ventricular } \\
\text { arrhythmias / potentially } \\
\text { life-threatening ventricular } \\
\text { arrhythmias }\end{array}$ & $\begin{array}{l}\text { The mean } 3.6 \text { days to the first } \\
24 \text { h ECG showing no VT }\end{array}$ & 58 \\
\hline 48 & $\begin{array}{l}\text { - responders: mean } \\
349 \pm 122 \mathrm{mg} / \text { day; } \\
\text { - nonresponders } \\
460 \pm 135 \mathrm{mg} / \text { day }\end{array}$ & $\begin{array}{l}\cdot \text { responders } \\
1.5 \pm 0.6 \text {; } \\
\cdot \text { nonresponders } \\
1.7 \pm 0.7\end{array}$ & & $\begin{array}{l}\text { Refractory symptomatic } \\
\text { atrial tachyarrhythmias }\end{array}$ & $\begin{array}{l}\text { Successfully controlled in } \\
41 \text { patients during a mean } \\
\text { follow-up of } 10.1 \text { months }\end{array}$ & 61 \\
\hline 50 & $\begin{array}{l}\cdot \text { responders: mean } \\
3371 \pm 145 \mathrm{mg} / \text { day; } \\
\cdot \text { nonresponders } \\
500 \pm 175 \mathrm{mg} / \text { day }\end{array}$ & $\begin{array}{l}\cdot \text { responders } \\
1.8 \pm 0.7 \text {; } \\
\cdot \text { nonresponders } \\
1.9 \pm 0.7\end{array}$ & & Sustained VT & $\begin{array}{l}38 \text { patients resonded during } \\
\text { a mean follow-up of } 10.9 \\
\text { months }\end{array}$ & \\
\hline
\end{tabular}


Table 3. Continued

\begin{tabular}{|c|c|c|c|c|c|c|}
\hline $\mathrm{n}$ & Dosage & Amiodarone (mg/L) & $\begin{array}{c}\text { DEA } \\
(\mathrm{mg} / \mathrm{L})\end{array}$ & $\begin{array}{l}\text { Type } \\
\text { of arrhythmia }\end{array}$ & Effect & Ref. \\
\hline 64 & $200-600 \mathrm{mg} /$ day & $0.8-8.0$ in responders & & $\begin{array}{l}\text { Supraventricular/ } \\
\text { ventricular } \\
\text { tachyarrhythmias }\end{array}$ & $\begin{array}{l}\text { Controlled in } 87.5 \% \text { of } \\
\text { patients during the mean } 5.5 \\
\text { months }\end{array}$ & 10 \\
\hline 127 & $\begin{array}{l}\text { loading doses } \\
600-1600 \mathrm{mg} / \text { day for } 10 \\
\text { to } 18 \text { days; maintenance } \\
\text { dose } 200-600 \mathrm{mg} \text { either } \\
6-7 \text { days per week }\end{array}$ & $\begin{array}{l}\text { - patients withount } \\
\text { reccurences: } \\
2.8 \pm 1.4(\mathrm{VA}) / \\
1.7 \pm 1.2(\mathrm{SA}) \\
\text { - patients with } \\
\text { reccurences: } \\
1.9 \pm 1.0(\mathrm{VA}) / \\
1.3 \pm 1.2(\mathrm{SA})\end{array}$ & $\begin{array}{l}\text { - patients } \\
\text { withount } \\
\text { reccurences: } \\
1.6 \pm 0.6 \text { (VA) } \\
/ 1.0 \pm 0.4 \text { (SA) } \\
\text { - patients with } \\
\text { reccurences: } \\
1.2 \pm 0.6 \text { (VA) / } \\
0.7 \pm 0.5 \text { (SA) }\end{array}$ & $\begin{array}{l}\text { Resistant ventricular } \\
\text { arrhythmis (VA) } \\
\text { / supraventricular } \\
\text { arrhythmias (SA) }\end{array}$ & $\begin{array}{l}\text { Supressed in } 78 \% \text { of patients } \\
\text { ( } 81 \% \text { of patients with VA / } \\
70 \% \text { of patients with SA) }\end{array}$ & 60 \\
\hline 25 & & $\begin{array}{l}\cdot>2.0 \\
->1.5\end{array}$ & & Complex VA & $\begin{array}{l}\text { - Significant reduction of } \\
\text { PVCs and pairer PVCs } \\
\text { and VT } \\
\text { - Significant reduction in VT }\end{array}$ & 62 \\
\hline 12 & $600 \mathrm{mg} /$ day & $0.86 \pm 0.48$ & $0.23 \pm 0.15$ & VPDs & $\begin{array}{l}\text { At least } 75 \% \text { suppression of } \\
\text { VPDs in } 13.2 \text { days (range } \\
1-36 \text { days) }\end{array}$ & 63 \\
\hline 24 & $\begin{array}{l}\text { loading: } 900 \mathrm{mg} / \mathrm{day} \\
(800-1200 \mathrm{mg}) \\
\text { maintenance: } 560 \mathrm{mg} / \\
\text { day }(400-800 \mathrm{mg})\end{array}$ & $\begin{array}{c}1.3 \\
\text { (range } 0.44-4.10)\end{array}$ & & Refractory VT & $\begin{array}{l}\text { Reduced spontaneous } \\
\text { arrhythmia in } 5 \text { patients after } \\
31 \text { days (range } 21-88 \text { ) } \\
\text { of therapy }\end{array}$ & 64 \\
\hline 40 & $\begin{array}{l}\text { - } 825 \pm 357 \mathrm{mg} / \mathrm{day} \\
\text { - } 776 \pm 301 \mathrm{mg} / \mathrm{day}\end{array}$ & $\begin{array}{l}\text { - } 1.37 \pm 0.63 \\
\text { - } 1.40 \pm 1.28\end{array}$ & $\begin{array}{l}\cdot 0.83 \pm 0.16 \\
\cdot 0.84 \pm 0.29\end{array}$ & Sustained VT/ VF & $\begin{array}{l}\text { - In } 9 \text { patients arrhythmia } \\
\text { could not be induced } \\
\text { - In } 31 \text { patients arrhythmia } \\
\text { could be induced }\end{array}$ & 65 \\
\hline
\end{tabular}

$\mathrm{n}$ - number of patient

pha- and beta - blockade effect (Vaughan-Williams class II effect) $\left(\right.$ ref. $\left.{ }^{27}\right)$. Acute amiodarone also caused a concentration-dependent decrease in delayed rectifier potassium current $^{28}$ and inhibition of ligand-gated potassium channel ${ }^{29}$. Amiodarone significantly shortened action potential duration (APD) in Purkinje fibers, while prolonging it in ventricular muscle cells ${ }^{30}$. Acute effects result clinically in a depressed automaticity of the sinoatrial (SA) node resulting in a decrease in sinus rate ${ }^{31}$ and increased refractoriness of the atrioventricular (AV) node resulting in depression of AV node function ${ }^{32}$. Amiodarone slows AV nodal conduction by blocking the calcium current ${ }^{33}$. However, the effects of the drug on AV node conduction are often masked by the effects of the reduction on the heart rate ${ }^{34}$. The QT interval has been shown to be relatively unaffected and a prolongation of effective refractory period (ERP) in ventriclular muscle is minimal or negligible ${ }^{26}$. In patients with impaired ventricular function though, intravenous amiodarone increased the right ventricular ERP and showed rate-dependent prolongation of the QRS interval ${ }^{5}$. In addition to electrophysiologic properties, intravenous amiodarone also has effects on hemodynamics. Despite negative inotropic effects on the left ventricle, the decrease in systemic vascular resistance and myocardial oxygen demand results in a slightly increased cardiac output ${ }^{35}$.

\section{Chronic therapy}

The major effect of chronic amiodarone therapy is inhibition of outward potassium currents (VaughanWilliams class III effect) resulting in a prolongation of APD, not only in atrial and ventricular muscles but also in the SA and AV nodes. This APD prolongation is associated with a comparable prolongation of ERP $\left(\right.$ ref. $\left.{ }^{36}\right)$. APD prolongation is most likely explained by a decrease of current density for delayed rectifier potassium current and 4AP-sensitive transient outward current. This may be due to a modulation of gene expression of ion channels ${ }^{26}$. Oral amiodarone has been shown to have significant effects on the QT interval in addition to slowing the sinus rate ${ }^{34}$. Desethylamiodarone (DEA), the major amiodarone metabolite, has stronger class I properties and weaker class IV actions than the parent compound $^{7}$. DEA produced concentration-related increases in QRS, QT, and QTc intervals with a potency significantly greater than that of amiodarone ${ }^{37}$. Therefore accumulation of DEA probably accounts for some of the delayed electrophysiologic effects in patients receiving long-term treatment with amiodarone ${ }^{38}$. The antiarrhythmic effect of DEA was shown to be in part dependent on gene expression rather than a direct effect on cell membrane channels or receptors ${ }^{39}$. 


\section{ADVERSE EFFECTS}

Amiodarone has been reported to cause a variety of cardiac and extracardiac side effects, both in its oral and intravenous formulation ${ }^{36}$. It alters thyroid metabolism (clinically hypo- or hyperthyroidism), both as a result of inhibition of deiodination of thyroxinE and as a result of iodine release from the amiodarone molecule. Amiodarone may produce excessive bradycardia, which is more likely in patients with sinus node dysfunction. It is generally considered to have a smaller proarrhythmic potential than other antiarrhythmic drugs ${ }^{7}$. Nevertheless, female sex is associated with an increased risk of torsades de pointes in the setting of potassium antagonists ${ }^{40}$. The risk of severe hypotension after intravenous amiodarone can be largely avoided by using a slower rate of infusion, especially in patients with hypovolemic status ${ }^{41}$. Hypotension may arise due in part, to polysorbate 80 , an excipient with vasodilator properties ${ }^{42}$. The development of corneal microdeposits and their rate of progression is dose-dependent, but discontinuation of amiodarone because of microdeposits is usually not necessary and in cases where amiodarone is withdrawn the ocular changes regress completely in 3-4 months. At normal doses, the probability that amiodarone is the cause of liver toxicity is actually quite $\operatorname{low}^{43}$. Dermatological side effects (for example photosensitivity) are common ${ }^{44}$ and several forms of pulmonary disease occur among patients treated with amiodarone with a prevalence about $5 \%\left(\mathrm{ref}^{45}\right)$.

\section{DRUG-DRUG INTERACTION}

Amiodarone influences the activity of many CYP enzymes and can lead to multiple drug interactions. It inhibits CYP1A2, CYP2C9, CYP2D6, CYP3A4 and also P-glycoprotein resulting mainly in increased concentrations of other drugs metabolized via these pathways. E.g., amiodarone administration results in $70 \%$ higher digoxin plasma concentrations after one day of concomitant administration. Co-medication with amiodarone also results in increased warfarin concentrations, which lead to elevated prothrombin time and international normalized ratio $^{35}$. The time course of onset of this interaction is highly variable, ranging from 1 to 28 days, in most cases the delay was longer than 6 days. Moreover the inhibition of warfarin metabolism may last 2 to 16 weeks after discontinuing amiodarone administration ${ }^{22}$. A significant interaction between amiodarone and metoprolol via DEAinduced inhibition of CYP2D6 has been reported ${ }^{16}$. On average, metoprolol plasma concentration was doubled after an amiodarone loading dose $(1.2 \mathrm{~g}$ /day over a period of 6 days). The interaction was more pronounced in patients with $\geq 2$ compared with 1 functional CYP2D6 allele, indicating a clear "gene-dose" relation ${ }^{46}$.

\section{RELATIONSHIP BETWEEN AMIODARONE DOSE/CONCENTRATION AND CARDIAC EFFECTS}

Differences between early and later antiarrhythmic effects remain, despite the achievement of comparable plasma amiodarone concentration ${ }^{47}$. The discrepancy between short- and long-term effects of amiodarone cannot be explained solely on the basis of amiodarone myocardial concentration because coronary arterial concentrations of amiodarone and myocardial concentrations after the second hour of intracoronary infusion were in the same range as those observed after long-term amiodarone treatment, however only conduction velocity was affected ${ }^{48}$.

\section{Intravenous administration}

It is well established that the onset of amiodarone antiarrhythmic action after oral administration may be delayed for several days. In contrast, an immediate therapeutic effect has been obtained after intravenous administration in a study by Rotmensch et al. ${ }^{10}$. However tachycardia re-occurred in 3 patients of 7 patients compared with long-term oral therapy. The authors concluded that oral therapy prevented recurrence and reinducibility by its predominant effect in prolonging refractoriness of the atrium and ventricle, and depressing conduction through the retrograde fast pathway ${ }^{49}$. Saksena et al. also observed no effect on cycle length of spontaneous ventricular tachycardia after intravenous administration ${ }^{50}$. Nanas et al. examined the time course of development of electrophysiological effects during intracoronary infusion of amiodarone in $\operatorname{dogs}^{48}$. A significant correlation was found between the extent of reduction of conduction velocity and myocardial amiodarone concentration but not coronary arterial or systemic concentration. In this study, amiodarone levels in the myocardium increased from a mean of $5.95 \mathrm{ug} / \mathrm{g}$ at $15 \mathrm{~min}$ of infusion to 188.88 $\mathrm{ug} / \mathrm{g}$ at the 10th hour. However the effect observed was initially very small and became pronounced only after several hours. In addition, no significant change in repolarization interval was observed at any time ${ }^{48}$. No change in the repolarization interval was observed after $10 \mathrm{~h}$ of amiodarone infusion in humans. At $2.5 \pm 1.2 \mathrm{~min}$ after amiodarone administration, the mean myocardial concentration was $95.7 \pm 67.4 \mathrm{ug} / \mathrm{g}$. In this study no significant electrocardiographic changes were measured. Species and methodological differences may account for these discrepant electrophysiologic effects (small sample size with wide range of amiodarone myocardial concentrations in study in humans and absence of evaluation of early antiarrhythmic effect) (ref. ${ }^{12}$ ). Scheinman et al. found a beneficial dose-response relationship using i.v. amiodarone in patients with life-threatening arrhythmias. Patients treated with 500 to $1000 \mathrm{mg}$ /day doses of i.v. amiodarone showed significantly lower event rates and longer time to arrhythmia recurrence than patients in the $125 \mathrm{mg}$ /day dose group. They found a significant dose-related increase in the time to first event and a significant dose-related decrease in the number of supplemental boluses per hour ${ }^{42}$. Similar results were suggested in the study by Kowey et 
al. which was designed to compare the safety and efficacy of a high and a low dose of intravenous amiodarone with bretylium. The primary analysis of the arrhythmia event rate during the first $48 \mathrm{~h}$ of therapy, showed comparable efficacy between the bretylium group and the high - dose ( $1000 \mathrm{mg} /$ day) amiodarone group that was greater than that of the low - dose (125 mg/day) amiodarone group. Similar results were obtained in the secondary analyses of time to first event and the proportion of patients requiring supplemental infusion ${ }^{51}$. In another study by Levine et al. no clear dose-response relation was found in the treatment of recurrent sustained hypotensive ventricular tachyarrhythmias, with respect to success rates, time to first recurrence of tachyarrhytmia or mortality over $24 \mathrm{~h}$. However, there was reported a significant dose-response relation between the 500-mg dose group and the combined 1000- and 2000-mg dose groups in the time to first event when the first $12 \mathrm{~h}$ were considered. This discrepancy could be explained by the small sample size of the study or the relative insensitivity of these end points ${ }^{52}$. Kinetic analysis of plasma levels of i.v. amiodarone $(5 \mathrm{mg} / \mathrm{kg}$ in 5 min) in four patients during the electrophysiological study (before and 1 and $2 \mathrm{~h}$ after injection) did not support a direct association between plasma concentration and its effect $^{53}$. We were unable to gain more informations about the study protocol.

\section{Oral administration}

Escoubet et al. showed the onset of the antiarrhythmic effect of a single oral dose of a $30-\mathrm{mg} / \mathrm{kg}$ of amiodarone within 4 to $5 \mathrm{~h}$ on premature complexes, within $3 \mathrm{~h}$ on atrioventricular node and after 2 to $8 \mathrm{~h}$ on VT in about $60 \%$ of patients ${ }^{54}$. In $28 \%$ of those with permanent fibrillation, amiodarone restored the sinus rhythm within $5 \pm 1.5$ h. A significant relationship between amiodarone plasma concentrations and the onset of the antiarrhythmic effect was observed, the threshold amiodarone plasma concentration averaged 1.5 to $2.0 \mathrm{mg} / \mathrm{L}$ and the associated myocardial concentration ranged from 10 to $20 \mathrm{mg} /$ $\mathrm{kg}$. In the analysis, patients with refractory arrhythmias were excluded. On the other hand, Nielsen and Moller using same dose of amiodarone were not able to convert to sinus rhythm though $71 \%$ patients reached the recommended plasma concentration of amiodarone (2.0$2.5 \mathrm{mg} / \mathrm{L})\left(\right.$ ref. $\left.^{55}\right)$. However, the concentration of DEA remained low. The discrepancy between these two studies may be caused by the type and duration of arrhythmias. While in the first study, there were patients with constant fibrillation which had been established for longer than 5 days, in the second, patients with chronic atrial fibrillation or flutter with a median duration of 10 months (range 3-45 months).

The importance of DEA plasma concentrations for conversion to sinus rhythm was demonstrated by Tielman et al. Conversion was related to increased desethylamiodarone plasma levels and concomitant treatment with verapamil. Patients with an amiodarone level $<1.2 \mathrm{mg} / \mathrm{L}$ or a desethylamiodarone level $<0.9 \mathrm{mg} / \mathrm{L}$ were unlikely to convert. This may be related to a high myocardium/ plasma concentration ratio in the case of desethylamio- darone. In contrast, reduction of the ventricular rate during ongoing atrial fibrillation was clearly correlated with plasma levels of amiodarone itself ${ }^{56}$.

The long delay between initiation of therapy and the onset of action remains a serious problem because with conventional loading regimens, mean delays of 9.5 days have been reported ${ }^{57}$. Mostow et al. tested the hypothesis that rapid loading with amiodarone to a target plasma concentration can overcome much of the long delay between the initiation of therapy and the onset of effective suppression of arrhythmia ${ }^{58}$. Dosage was adjusted on the basis of amiodarone serum concentrations to maintain the trough serum concentrations between $2.0-3.0 \mathrm{mg} / \mathrm{L}$. A significant reduction in premature ventricular complexes (PVCs) and paired PVCs was observed beginning on the first day of therapy and a reduction in ventricular tachycardia beginning on the second day. In spite of the large doses of amiodarone used, hemodynamic monitoring revealed no significant change in cardiac output, pulmonary capillary pressure or blood pressure.

Greenberg et al. compared electrophysiological parameters after 9 days of acute amiodarone loading dose (1200-1400 mg/day) and after an additional month of maintenance therapy ( $400 \mathrm{mg} /$ day) in patients with sustained ventricular tachycardia ${ }^{59}$. Both short- and long-term amiodarone therapy caused significant changes in QTc, right ventricular effective refractory period and ventricular tachycardia cycle length. However, there was no significant change in electrophysiological parameters between the end of the acute amiodarone loading period and 1 month of additional therapy. Amiodarone and desethylamiodarone plasma concentrations remained stable after amiodarone loading dose $(1.19 \pm 0.13$ and $0.72 \pm 0.06 \mathrm{mg} / \mathrm{L}$ after loading dose; $1.08 \pm 0.22$ and $0.84 \pm 0.05 \mathrm{mg} / \mathrm{L}$ after an additional month of maintenance therapy), but this did not correlate with the magnitude of electrophysiological changes.

Rotmensch et al. found that in patients who had treatment-resistant ventricular or supraventricular arrhythmias or were intolerant to other drugs, arrhythmias recurred in $47 \%$ of patients with serum amiodarone concentrations of less than $1.0 \mathrm{mg} / \mathrm{L}$ whereas in only $14 \%$ of patients with higher concentrations recurrences were observed ${ }^{60}$. Although in long-term amiodarone therapy of refractory symptomatic atrial and symptomatic life threatening-ventricular tachyarrhythmias, the mean serum amiodarone concentration did not differ between responders and nonresponders, some of responders relapsed when their serum concentration fell below $1.0 \mathrm{mg} / \mathrm{L}$ (ref. ${ }^{61}$ ). Similarly, in another study by Rotmensch et al. serum amiodarone concentrations in patients whose supraventricular and ventricular tachyarrhythmias were controlled were not predictive of clinical efficacy ${ }^{10}$. In a retrospective study by Mostow at al., reduction in the frequencies of PVCs and paired PVCs, as well as ventricular tachycardia was linked with trough plasma amiodarone concentrations greater than $2.0 \mathrm{mg} / \mathrm{L}$, resp. $1.5 \mathrm{mg} / \mathrm{L}$. Even negative correlations between serum amiodarone concentration and the frequencies of PVCs, paired PVCs and ventricular tachycardia were found. No correlations existed between amiodarone dose and these arrhythmias ${ }^{62}$. From these 
studies it can be concluded, that keeping plasma concentration at least above $1.0 \mathrm{mg} / \mathrm{L}$ seems to be optimal for prevention of recurrences.

In contrast, Conolly et al. observed that $67 \%$ of patients with frequent ventricular premature depolarizations (VPDs) responded at amiodarone concentrations below $1.0 \mathrm{mg} / \mathrm{L}$ (ref. ${ }^{63}$ ). This concentration is considerably lower than that reported previously. The main difference between this study and Mostow et al. ${ }^{62}$ is that in the former, the lowest concentration associated with an antiarrhythmic response was systematically determined by repeated Holter monitoring during drug loading dose. In previous studies, serum concentrations were analyzed retrospectively in patients receiving amiodarone without any systematic attempt being made to determine the lowest concentration associated with an effect. A relationship between amiodarone and DEA plasma concentrations and suppression of VPDs was observed in all patients, which suggests that concentrations of amiodarone and its metabolite are an important factor in determining the antiarrhythmic effect of amiodarone. There was a trend for DEA to be more strongly related than amiodarone. For each patient there was a progressive decrease in frequency of VPDs as both amiodarone and desethylamiodarone concentrations increased. The patients in this study were not being treated for sustained ventricular tachycardia or fibrillation. Therefore the results of this study should not be extrapolated to patients with sustained ventricular arrhythmias $^{63}$.

In the publication by Saksena at al., serum amiodarone levels were unrelated to therapeutic response and a multiple linear regression analysis did not show any correlation of serum levels with the changes in ECG or electrophysiologic parameters. In this study, serum DEA concentrations were not assessed. Although the arrhythmia recurrence rate on amiodarone was still substantial $(21 \%)$, these arrhythmias were much better tolerated ${ }^{64}$. Similarly Greenberg et al. found no correlation between either amiodarone plasma level or drug dose and any electrophysiological effect measured after one month of treatment with oral amiodarone ${ }^{65}$. The opposite results were reported by Debbas et al. who found good correlation between plasma and myocardial concentrations, and both correlated well with the percentage increase in the QTc interval ${ }^{66}$. However, the sample was small and the mean amiodarone concentration very low ${ }^{65}$.

With reference only to amiodarone dosage Ward et al. observed that only six of 23 patients with total supression required the maintenance dose of amiodarone more than $200 \mathrm{mg}$ daily whereas Rosenbaum et al. reported a maintenance dose greater than $300 \mathrm{mg} /$ daily in 9 of 11 patients ${ }^{67}$. This discrepancy could be due to differences in patients.

The controversial results of individual studies may result from various criteria for efficacy (e.g. elimination of spontaneous ventricular ectopic activity vs. supression of sustained arrhythmias), patient selection, severity of underlying heart disease, duration of follow-up and monitoring before study, the timing of the efficacy assessment and drug dosage schedules. Each type of arrhythmia may also require different dosage, resp. serum concentrations.

\section{Oral versus intravenous amiodarone administration}

Intravenous amiodarone can be successful in suppressing life-threatening ventricular arrhythmias even when chronic oral amiodarone has failed, as concluded by Kavesh et al. In this case report, the patient experienced "electrical storm" despite long-term oral use of amiodarone (400 mg/day) with an amiodarone plasma level of $2.546 \mathrm{mg} / \mathrm{L}$ (DEA level of $1.361 \mathrm{mg} / \mathrm{L}$ ). However, his arrhythmia was successfully treated by i.v. amiodarone $(150 \mathrm{mg} / 10 \mathrm{~min}$, then $1 \mathrm{mg} / \mathrm{min}$ for $6 \mathrm{~h}$, followed by $0.5 \mathrm{mg} / \mathrm{min}$ ). After 6 weeks of continuous i.v. amiodarone therapy, during which time sustained ventricular arrhythmias did not occur, cardiac transplantation was performed. The amiodarone level was $1.796 \mathrm{mg} / \mathrm{L}$ and DEA level was $1.684 \mathrm{mg} / \mathrm{L}$ two days prior to transplantation. This appears to be due to different mechanism of action of the two formulations. Earlier experiments in rats suggest that intravenous amiodarone has a much more potent sympatholytic effect at the myocardial level than the oral formulation. There are also differences in the hemodynamic responses-i.v. amiodarone results in vasodilatation, increased coronary artery blood flow, left ventricular filling pressures and cardiac output, while oral amiodarone can decrease cardiac index despite vasodilatation $^{68}$.

\section{THERAPEUTIC DRUG MONITORING (TDM)}

In 1969, the antiarrhythmic effect of amiodarone was observed in experimental animal models. However, the relationship between dose, plasma concentration and effect is still unclear ${ }^{26,69}$. The use of amiodarone is complicated by its very unusual pharmacokinetics ${ }^{69}$. The plasma levels resulting from orally administered amiodarone varied considerably between individuals ${ }^{14}$ and considerable interindividual variation is found with regard to the minimum effective concentration of amiodarone. This indicates that measurment of amiodarone or DEA concentrations alone cannot replace assessment of the clinical response to treatment of individual patients ${ }^{63}$. While efficacy has been observed for amiodarone plasma concentrations as low as 0.1 and as high as $11.9 \mathrm{mg} / \mathrm{L}$ (ref. ${ }^{22}$ ), there are some studies showing that plasma levels of $1.0-1.5 \mathrm{mg} / \mathrm{L}$ are associated with a decrease in the amount of ventricular ectopy, and that levels $>2.5 \mathrm{mg} / \mathrm{L}$ do not provide any additional antiarrhythmic benefit ${ }^{36}$. Other authors suggested that lower amiodarone plasma concentration (above 0.5 $\mathrm{mg} / \mathrm{L}$ ) seems to be sufficient for efficacy, but there are no convincing data showing a correlation between actual plasma concentration and antiarrhythmic effect. Similarly, serious toxicity seems to be more likely at concentrations above $2.5 \mathrm{mg} / \mathrm{L}$ but its incidence correlates more with cumulative dose, suggesting the importance of amiodarone accumulation in target tissues over time ${ }^{69}$.

Plasma concentrations, although potentially useful for monitoring long-term therapy, are likely to be unhelpful or misleading during the 4- to 6-week loading period at the beginning of treatment because rising plasma concentrations before steady state are not in equilibrium with tissue 
concentrations $^{9,15}$. During maintenance therapy, plasma amiodarone concentrations are probably in equilibrium with the higher amounts of amiodarone found in body tissues. This may explain why the plasma concentrations during long-term therapy fluctuate little compared with single-dose kinetics. Thus, plasma levels during chronic therapy may reflect tissue levels and therapeutic effect more accurately than they would during acute administration $^{61}$. Robinson et al. indicated that neither the plasma concentrations of amiodarone nor its metabolite show any significant change with time once steady state has been achieved, suggesting that amiodarone neither inhibits nor enhances its own metabolism ${ }^{70}$. No relationship between height and weight, and plasma concentrations of the drug were found either and even dose was a poor predictor of the steady state amiodarone concentration. However in chronic oral therapy compliance should be taken into account. In contrast, Mailing et al. defined individual variability of amiodarone distribution during long-term stable amiodarone therapy in plasma and erythrocytes. The data underlined the highly variable cellular distribution of amiodarone and DEA in the same patient on stable dosage over time. The authors concluded that no a clinically useful relationship between plasma concentration and effect could be consistently demonstrated for amiodarone in the same individual during stable dos$\mathrm{age}^{71}$. However, we were unable to find any information about the study protocol. The absorption of amiodarone following nasogastric administration is poor compared with oral administration. To achieve similar concentrations, an approximately 3 -fold increase in dosage of amiodarone was required when patients were given the drug nasogastrically rather than orally. In this case, therapeutic drug monitoring is necessary to optimize dose particularly during the early stages of amiodarone therapy ${ }^{72}$. Candinas et al. found a good correlation between myocardial concentration of amiodarone and desethylamiodarone and the cumulative ingested dose of amiodarone. Tissue drug concentrations correlated only poorly with plasma amiodarone and DEA levels. Their data confirm the slow equilibrium of amiodarone and DEA concentrations between plasma and myocardium. Therefore, monitoring of the total cumulative dose may be more relevant clinically than monitoring plasma levels ${ }^{73}$.

With respect to adverse effects, corneal deposits seem to correlate with dosage and duration of treatment ${ }^{74}$. Hypotension usually occurs during the highest rate of intravenous drug delivery with no significant dose-related increase ${ }^{42}$. The majority of patients, who developed pulmonary toxicity, were being given maintenance doses greater than $400 \mathrm{mg} /$ day $^{75}$. Elevation of hepatic enzyme activities was related to higher mean daily dose and plasma concentrations of amiodarone in study by Greenberg et al. whereas skin discoloration was related to accumulated dose ${ }^{65}$.

Another way of interpreting plasma amiodarone and DEA levels is attempting to determine an "individual therapeutic concentration"76. This means the concentration at which a "pharmacological" arrhythmias is achieved.

\section{CONCLUSION}

Association between amiodarone and desethylamiodarone plasma level and their clinical efficacy is difficult to evaluate. The effects of acute and chronic as well intravenous and oral amiodarone differ, independently of the achievement of comparable plasma/myocardial amiodarone concentration. Although several studies show that plasma concentration range between 0.5 and $2.5 \mathrm{mg} / \mathrm{L}$ appears to be the most effective, others demonstrate no difference between responders and non-responders in terms of to plasma levels. Nevertheless keeping plasma concentration at least above $0.5 \mathrm{mg} / \mathrm{L}$, resp. $1.0 \mathrm{mg} / \mathrm{L}$ seems to be optimal. Another way of interpreting plasma amiodarone levels is to establish individual concentration at which optimal therapeutic response is achieved.

\section{Search strategy and selection criteria}

Our research strategy was aimed at evaluating studies on any objective correlation between amiodarone and desethylamiodarone plasma level and their clinical effect. We summarized the results of studies using PubMed database (English-language reports from 1967 to November 2015) and clarified the relationship between plasma levels and effect with respect to the pharmacokinetics and pharmacogenetics of amiodarone. The search terms used included "amiodarone", "plasma levels and effect", "pharmacokinetics", "pharmacogenetics" and "therapeutic drug monitoring”.

\section{ABBREVIATIONS}

ICD, implantable cardioverter-defibrillator; VT, ventricular tachycardia; VF, ventricular fibrillation; APD, action potential duration; SA, sinoatrial; AV, atrioventricular; ERP, effective refractory period; DEA, desethylamiodarone; MRP, multidrug resistance-associated proteins; BCRP, breast cancer resistance protein; $\mathrm{ABC}$, ATP-binding cassette; t1/2, half-life; CYP, cytochrom P450; PVCs, premature ventricular complexes; ECG, electrocardiogram; VPDs, ventricular premature depolarizations; VA, ventricular arrhythmis; SA, supraventricular arrhythmias; TDM, therapeutic drug monitoring

Acknowledgment: This project was supported by grant of University of Ostrava SGS15/LF/2016-2017.

Author contributions: EHV: manuscript writing, literature search; MG: final approval; JD: literature search; IK: conception and manuscript writing.

Conflict of interest statement: The authors state that there are no conflicts of interest regarding the publication of this article.

\section{REFERENCES}

1. Kumar K, Zimetbaum PJ. Antiarrhythmic drugs 2013: state of the art. Curr Cardiol Rep 2013;15(10):410. doi:10.1007/s11886-013-0410-2 2. Riva E, Gerna M, Latini R, Giani P, Volpi A, Maggioni A. 
Pharmacokinetics of amiodarone in man. J Cardiovasc Pharmacol 1982;4(2):264-9.

3. Andreasen F, Agerbaek H, Bjerregaard P, Gøtzsche $H$ Pharmacokinetics of amiodarone after intravenous and oral administration. Eur J Clin Pharmacol 1981;19(4):293-9.

4. Kashima A, Funahashi M, Fukumoto K et al. Pharmacokinetic characteristics of amiodarone in long-term oral therapy in Japanese population. Biol Pharm Bull 2005;28(10):1934-8.

5. Shiga T, Tanaka T, Irie S, Hagiwara N, Kasanuki H. Pharmacokinetics of intravenous amiodarone and its electrocardiographic effects on healthy Japanese subjects. Heart Vessels $2011 ; 26(3): 274-81$. doi:10.1007/s00380-010-0047-7

6. Veronese ME, McLean S, Hendrik R. Plasma protein binding of amiodarone in a patient population: measurement by erythrocyte partitioning and a novel glass-binding method. Br J Clin Pharmacol 1988;26(6):721-31.

7. Nattel S, Talajic M, Fermini B, Roy D. Amiodarone: Pharmacology, Clinical Actions, and Relationships Between Them. J Cardiovasc Electrophysiol 1992;3(3):266-80.

8. Holt DW, Tucker GT, Jackson PR, Storey GC. Amiodarone pharmaco kinetics. Am Heart J 1983;106(4 Pt 2):840-7.

9. Pollak PT, Bouillon T, Shafer SL. Population pharmacokinetics of long term oral amiodarone therapy. Clin Pharmacol Ther 2000;67(6):64252.

10. Rotmensch HH, Swanson BN, Greenspon AJ, Shoshani D, Greenspan AM. Amiodarone: individualizing dosage with serum concentrations. Pacing Clin Electrophysiol 1983;6(6):1327-35

11. Heger JJ, Prystowsky EN, Zipes DP. Relationships between amiodarone dosage, drug concentrations, and adverse side effects. Am Heart J 1983;106(4 Pt 2):931-5.

12. Anastasiou-Nana MI, Nanas JN, Alexopoulos G, Karli JN, Margari ZJ, Agapitos E, Patsi EN, Stamatelopoulos SF. Amiodarone concentration in human myocardium after rapid intravenous administration. Cardiovasc Drugs Ther 1999;13(3):265-70.

13. Robson' DJ, Jeeva Raj MV, Storey CAG, Holt DW. Use of amiodarone during pregnancy. Postgrad Med J 1985;61:75-7. doi:10.1136/ pgmj.61.711.75

14. Anastasiou-Nana M, Levis GM, Moulopoulos S. Pharmacokinetics of amiodarone after intravenous and oral administration. Int J Clin Pharmacol Ther Toxicol 1982;20(11):524-9.

15. Siddoway LA, McAllister CB, Wilkinson GR, Roden DM, Woosley RL. Amiodarone dosing: a proposal based on its pharmacokinetics. Am Heart J 1983;106(4 Pt 2):951-6.

16. Fukumoto K, Kobayashi T, Tachibana K, Kato R, Tanaka K, Komamura K, Kamakura S, Kitakaze M, Ueno K. Effect of amiodarone on the serum concentration/dose ratio of metoprolol in patients with cardiac arrhythmia. Drug Metab Pharmacokinet 2006;21(6):501-5.

17. Ha HR, Bigler L, Binder M, Kozlik P, Stieger B, Hesse M, Altorfer HR, Follath F. Metabolism of amiodarone (part I): identification of a new hydroxylated metabolite of amiodarone. Drug Metab Dispos 2001;29(2):152-8.

18. Ohyama K, Nakajima M, Nakamura S, Shimada N, Yamazaki H, Yokoi T. A significant role of human cytochrome P450 2C8 in amiodarone $\mathrm{N}$-deethylation: an approach to predict the contribution with relative activity factor. Drug Metab Dispos 2000;28(11):1303-10.

19. Elsherbin ME, El-Kadi AO, Brocks DR. The metabolism of amiodarone by various CYP isoenzymes of human and rat, and the inhibitory influence of ketoconazole. J Pharm Pharm Sci 2008;11(1):147-59.

20. Soyama A, Hanioka N, Saito Y, Murayama N, Ando M, Ozawa S, Sawada J. Amiodarone N-deethylation by CYP2C8 and its variants, CYP2C8*3 and CYP2C8 P404A. Pharmacol Toxicol 2002;91(4):174-8.

21. García-Martín E, Martínez C, Ladero JM, Agúndez JA. Interethnic and intraethnic variability of CYP2C8 and CYP2C9 polymorphisms in healthy individuals. Mol Diagn Ther 2006;10(1):29-40.

22. Latini R, Tognoni G, Kates RE. Clinical pharmacokinetics of amiodarone. Clin Pharmacokinet 1984;9(2):136-56

23. Harris L, Hind CR, McKenna WJ, Savage C, Krikler SJ, Storey GC, Holt DW. Renal elimination of amiodarone and its desethyl metabolite. Postgrad Med J 1983;59(693):440-2.

24. Chow MS. Intravenous amiodarone: pharmacology, pharmacokinetics, and clinical use. Ann Pharmacother 1996;30(6):637-43

25. Ikeda N, Nademanee K, Kannan R, Singh BN. Electrophysiologic effects of amiodarone: experimental and clinical observation relative to serum and tissue drug concentrations. Am Heart J 1984;108(4 Pt 1):890-8
26. Kodama I, Kamiya K, Toyama J. Cellular electropharmacology of amiodarone. Cardiovasc Res 1997;35(1):13-29.

27. Charlier R. Cardiac actions in the dog of a new antagonist of adrenergic excitation which does not produce competitive blockade of adrenoceptors. Br J Pharmacol 1970;39(4):668-74.

28. Kodama I, Kamiya K, Honjo H, Toyama J. Acute and chronic effects of amiodarone on mammalian ventricular cells. Jpn Heart J 1996:37(5):719-30.

29. Mori K, Saito T, Masuda Y, Nakaya H. Effects of class III antiarrhythmic drugs on the $\mathrm{Na}(+)$-activated $\mathrm{K}+$ channels in guinea-pig ventricular cells. Br J Pharmacol 1996;119(1):133-41.

30. Yabek SM, Kato R, Singh BN. Acute effects of amiodarone on the electrophysiologic properties of isolated neonatal and adult cardiac fibers. J Am Coll Cardiol 1985;5(5):1109-15.

31. Goupil N and Lenfant J. The effects of amiodarone on the sinus node activity of the rabbit heart. Eur J Pharmacol 1976;39(1):23-31.

32. Pickoff AS, Singh S, Flinn CJ, Torres E, Ezrin AM, Gelband H. Dosedependent electrophysiologic effects of amiodarone in the immature canine heart. Am J Cardiol 1983;52(5):621-5.

33. Nattel S, Talajic M, Quantz M, DeRoode M. Frequency-dependent effects of amiodarone on atrioventricular nodal function and slowchannel action potentials: evidence for calcium channel-blocking activity. Circulation 1987;76(2):442-9.

34. Hamer AW, Mandel WJ, Zaher CA, Karagueuzin HS, Peter T. The electrophysiologic basis for the use of amiodarone for treatment of cardiac arrhythmias. Pacing Clin Electrophysiol 1983;6(4):784-94.

35. Cahoon W Jr, Flattery MP, Hess ML. Amiodarone: development, clinical indications, and safety. Prog Cardiovasc Nurs 2007;22(3):173-6.

36. Van Herendael $\mathrm{H}$ and Dorian P. Amiodarone for the treatment and prevention of ventricular fibrillation and ventricular tachycardia.Vasc Health Risk Manag 2010;6(9):465-7.

37. Nattel S. Pharmacodynamic studies of amiodarone and its active N-desethyl metabolite. J Cardiovasc Pharmacol 1986;8(4):771-7.

38. Talajic M, DeRoode MR, Nattel S. Comparative electrophysiologic effects of intravenous amiodarone and desethylamiodarone in dogs: evidence for clinically relevant activity of the metabolite. Circulation 1987;75(1):265-71.

39. Varbiro G, Toth A, Tapodi A, Bognar Z, Veres B, Sumegi B, Gallyas F Jr. Protective effect of amiodarone but not $\mathrm{N}$-desethylamiodarone on postischemic hearts through the inhibition of mitochondrial permeability transition. J Pharmacol Exp Ther 2003;307(2):615-25.

40. Wolbrette DL. Risk of proarrhythmia with class III antiarrhythmic agents: sex-based differences and other issues. Am J Cardiol 2003;91(6A):39D-44D.

41. Munoz A, Karila P, Gallay P, Zettelmeier F, Messner P, Mery M, Grolleau R. A randomized hemodynamic comparison of intravenous amiodarone with and without Tween 80. Eur Heart J 1988;9(2):142-8.

42. Scheinman MM, Levine JH, Cannom DS, Friehling T, Kopelman HA, Chilson DA, Platia EV, Wilber DJ, Kowey PR. Dose-ranging study of intravenous amiodarone in patients with life-threatening ventricular tachyarrhythmias. The Intravenous Amiodarone Multicenter Investigators Group. Circulation 1995;92(11):3264-72.

43. Pollak PT. How Toxic is Amiodarone to the Liver? J Gastrointestin Liver Dis 2010;19(1):11-3.

44. Shukla R, Jowett NT, Thompson DR, Pohl JE. Side effects with amiodarone therapy. Postgrad Med J 1994;70(825):492-8.

45. Schwaiblmair M, Berghaus T, Haeckel T, Wagner T, von Scheidt W. Amiodarone-induced pulmonary toxicity: an under-recognized and severe adverse effect? Clin Res Cardiol 2010;99(11):693-700. doi:10.1007/s00392-010-0181-3

46. Werner D, Wuttke H, Fromm MF, Schaefer S, Eschenhagen T, Brune K, Daniel WG, Werner U. Effect of amiodarone on the plasma levels of metoprolol. Am J Cardiol 2004;94(10):1319-21.

47. Nattel S, Davies M, Quantz M. The antiarrhythmic efficacy of amiodarone and desethylamiodarone, alone and in combination, in dogs with acute myocardial infarction. Circulation 1988;77(1):200-8.

48. Nanas JN, Mason JW. Pharmacokinetics and regional electrophysiological effects of intracoronary amiodarone administration. Circulation 1995;91(2):451-61.

49. Gambhir DS, Bhargava M, Nair M, Arora R, Khalilullah M. Comparison of electrophysiologic effects and efficacy of single-dose intravenous and long-term oral amiodarone therapy in patients with AV nodal reentrant tachycardia. Indian Heart J 1996;48(2):133-7.

50. Saksena S, Rothbart ST, Shah Y, Cappello G. Clinical efficacy and electropharmacology of continuous intravenous amiodarone infusion 
and chronic oral amiodarone in refractory ventricular tachycardia. Am J Cardiol 1984;54(3):347-52.

51. Kowey PR, Levine JH, Herre JM, Pacifico A, Lindsay BD, Plumb VJ, Janosik DL, Kopelman HA, Scheinman MM. Randomized, doubleblind comparison of intravenous amiodarone and bretylium in the treatment of patients with recurrent, hemodynamically destabilizing ventricular tachycardia or fibrillation. The Intravenous Amiodarone Multicenter Investigators Group. Circulation 1995;92(11):3255-63.

52. Levine JH, Massumi A, Scheinman MM, Winkle RA, Platia EV, Chilson DA, Gomes A, Woosley RL. Intravenous amiodarone for recurrent sustained hypotensive ventricular tachyarrhythmias. Intravenous Amiodarone Multicenter Trial Group. J Am Coll Cardiol 1996;27(1):6775.

53. Giani $P$, Maggioni AP, Volpi A, Cavalli A, Latini R, Neyroz P, Riva E, D'Aranno V. Blood levels and electrophysiological effects of intravenous amiodarone in patients with junctional reciprocating tachycardia. Preliminary observations. Acta Cardiol 1984;39(1):9-17.

54. Escoubet $B$, Coumel $P$, Poirier JM, Maison-Blanche $P$, Jaillon $P$, Leclercq JF, Menasche P, Cheymol G, Piwnica A, Lagier G, et al. Suppression of arrhythmias within hours after a single oral dose of amiodarone and relation to plasma and myocardial concentrations. Am J Cardiol 1985;55(6):696-702.

55. Nielsen KD and Møller S. Amiodarone for rapid cardioversion of chronic atrial tachyarrhythmia? Pharmacol Toxicol 2000;86(6):283-6.

56. Tieleman RG, Gosselink AT, Crijns HJ, van Gelder IC, van den Berg MP, de Kam PJ, van Gilst WH, Lie KI. Efficacy, safety, and determinants of conversion of atrial fibrillation and flutter with oral amiodarone. Am J Cardiol 1997;79(1):53-7.

57. Kaski JC, Girotti LA, Messuti H, Rutitzky B, Rosenbaum MB. Longterm management of sustained, recurrent, symptomatic ventricular tachycardia with amiodarone. Circulation 1981;64(2):273-9.

58. Mostow ND, Vrobel TR, Noon D, Rakita L. Rapid suppression of complex ventricular arrhythmias with high-dose oral amiodarone. Circulation 1986;73:1231-8.

59. Greenberg ML, Lerman BB, Haines DE, Baron JA, Dimarco JP. Stability of electrophysiological parameters after acute amiodarone loading: implications for patient management. Pacing Clin Electrophysiol 1989;12(7 Pt 1):1038-43.

60. Rotmensch HH, Belhassen B, Swanson BN, Shoshani D, Spielman SR, Greenspon AJ, Greenspan AM, Vlasses PH, Horowitz LN. Steady- state serum amiodarone concentrations: relationships with antiarrhythmic efficacy and toxicity. Ann Intern Med 1984;101(4):462-9.

61. Haffajee $\mathrm{Cl}$, Love JC, Canada AT, Lesko LJ, Asdourian G, Alpert JS Clinical pharmacokinetics and efficacy of amiodarone for refractory tachyarrhythmias. Circulation 1983;67(6):1347-55.

62. Mostow ND, Rakita L, Vrobel TR, Noon DL, Blumer J. Amiodarone: correlation of serum concentration with suppression of complex ventricular ectopic activity. Am J Cardiol 1984;54(6):569-74.

63. Connolly SJ, Gupta RN, Hoffert D, Roberts RS. Concentration response relationships of amiodarone and desethylamiodarone. Am Heart J 1988;115(6):1208-13.

64. Saksena S, Rothbart ST, Cappello G. Chronic effects of amiodarone in patients with refractory ventricular tachycardia. Int J Cardiol 1983;3(3):339-52.

65. Greenberg ML, Lerman BB, Shipe JR, Kaiser DL, DiMarco JP. Relation between amiodarone and desethylamiodarone plasma concentrations and electrophysiologic effects, efficacy and toxicity. J Am Coll Cardiol 1987;9(5):1148-55.

66. Debbas NM, du Cailar C, Bexton RS, Demaille JG, Camm AJ, Puech P. The QT interval: a predictor of the plasma and myocardial concentrations of amiodarone. Br Heart J 1984;51(3):316-20.

67. Ward DE, Camm AJ, Spurrell RA. Clinical antiarrhythmic effects of amiodarone in patients with resistant paroxysmal tachycardias. $\mathrm{Br}$ Heart J 1980;44(1):91-5.

68. Kavesh NG, Olsovsky MR, Freudenberger RS, Conte JV, Peters RW Shorofsky SR, Gold MR. Intravenous amiodarone suppression of electrical storm refractory to chronic oral amiodarone. Pacing Clin Electrophysiol 1999;22(4 Pt 1):665-7.

69. Campbell TJ and Williams KM. Therapeutic drug monitoring: antiarrhythmic drugs. Br J Clin Pharmacol 2001;52(S1):21S-34S.

70. Robinson K, Johnston A, Walker S, Mulrow J, Holt D, McKenna W. Stability of plasma amiodarone levels during chronic oral therapy. Cardiovasc Drugs Ther 1990;4(2):529-30.

71. Maling TJ, Siebers RW, Burgess CD, Taylor C, Purdie G. Individual variability of amiodarone distribution in plasma and erythrocytes: implications for therapeutic monitoring. Ther Drug Monit 1989;11(2):121-6.

72. Kotake T, Takada M, Goto T, Komamura K, Kamakura S, Morishita H Serum amiodarone and desethylamiodarone concentrations following nasogastric versus oral administration. J Clin Pharm Ther 2006;31(3):237-43.

73. Candinas R, Frielingsdorf J, Ha HR, Carrel T, Turina M, Follath F. Myocardial amiodarone concentrations after short- and longterm treatment in patients with end-stage heart failure. Eur J Clin Pharmacol 1998;53(5):331-6.

74. Kaplan LJ, Cappaert WE. Amiodarone-induced corneal deposits. Ann Ophthalmol 1984;16(8):762-6.

75. Rakita L, Sobol SM, Mostow N, Vrobel T. Amiodarone pulmonary toxicity. Am Heart J 1983;106(4 Pt 2):906-16.

76. Burton ME. Applied pharmacokinetics: principles of therapeutic drug monitoring. 4th ed. Baltimore: Lippincott Williams; 2006 p. 446-57. 